Chapter 9

\title{
Castor Breeding
}

\author{
Máira Milani and \\ Márcia Barreto de Medeiros Nóbrega \\ Additional information is available at the end of the chapter \\ http://dx.doi.org/10.5772/56216
}

\section{Introduction}

Produced from the seeds of Ricinus communis, castor oil is an important feedstock for the chemical industry because it is the only commercial source of ricinoleic acid, a hydroxy fatty acid, which comprises about $90 \%$ of the oil. In addition to the traditional uses of ricinoleic acid, there is also a demand for vegetable oil to be used as biofuel and for nem products derived from the castor oil. Due to the increasing demand in the global market, there is a short supply of castor oil and this trend seems to get worst every year. Castor is an ideal candidate for production of high value, industrial oil feedstocks because of the very high oil content (48-60\%) of the seed, and the extremely high levels of potential oil production [1] Due to the ricinoleic acid, castor oil and its derivatives are of great versatility being used in synthesis routes for a large number of products and are increasing rapidly [2,3]. In some places of the world it is used like an ornamental due to their vibrant leaf and floral coloration [4].

All over the world, cultivation is done by small farmers in countries such as India, China, and Brasil, and FAO statistics report seed yield averages of 1,104.8; 911.8; and 701.1kg/ha respectively for these countries (Figure 1). In Brazil and in India, the production is made in arid or semiarid regions. In these environments, the rainfall, is generally erratic and low, and the availability of water is the major factor affecting yield.

In Brazil, the production of castor oil is concentrated in the semi-arid northeast, mainly in the state of Bahia, which accounts for more than $80 \%$ of the production and acreage $[6,7]$. The culture system used by small producers in Brazil usually involves intercropping with food crops mainly maize and beans, and low adoption of technologies. The whole system of production, from planting to processing is manual [8]. Mostly the use of local varieties with long cycle and uneven seed maturation, little or no soil tillage and fertilization. Using such technology farmers have low-income, and the national seed yield of castor is low as $600 \mathrm{~kg} / \mathrm{ha}$ 
[7]. These values are too low to make the production profitable. The cultivars developed by Embrapa Cotton for the traditional areas of cultivation of castor, produce an average of 1500 $\mathrm{kg} / \mathrm{ha}$ of castor in farmers fields [9].

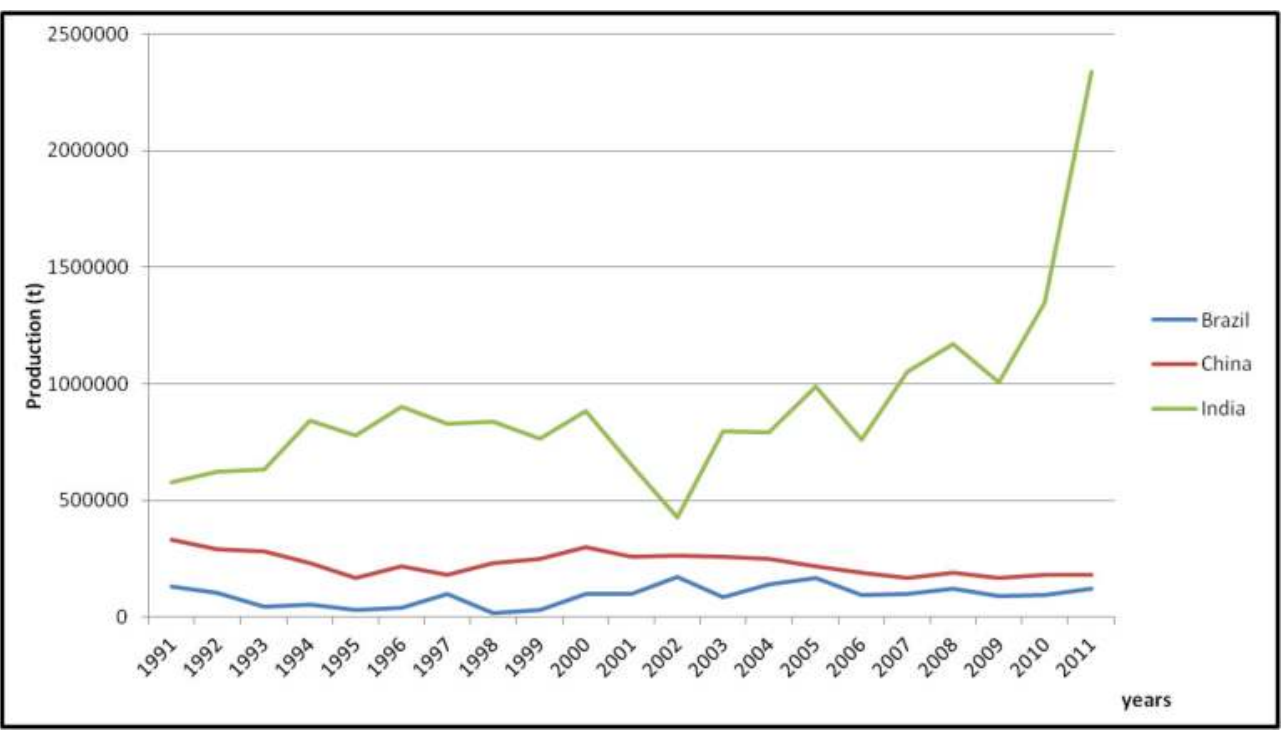

Figure 1. Yield of castor seed in the three main producers countries in twenty years. Data Source: [5]

The populations synthesized by the breeding program of Embrapa Cotton have been evaluated along with public and private partners since 1987. The Research Group mainly evaluates selected genotypes based on the behavior per se of individuals or populations. The main objective is to obtain cultivar that are more productive and adapted to the environment of each growing region, to the production system, and the technological level applied.

The program aims to develop cultivars that are indehiscent, short, and easy to harvest. Earliness of seed maturation is also desired.

\section{Genetic resources}

The taxonomy and geographic distribution were thoroughly studied and documented earlier in USSR [10], USA [1], Brazil [11] and India [12,13,14]. Castor is reported to have a polyphyletic origin, both India and Africa were considered as the origin of castor based on its widespread cultivation, documents of its medicinal uses and physical evidences. Due to its widespread survival and perennial nature, all possible transitions from an uncultivated plant to a weedy plant and from semi cultivated to a field crop exist and there is no gap between uncultivated and cultivated castor. 
The genetic diversity in castor is restricted due to its monotypic existence. Six subspecies viz., persicus, chinensis, zanzibarinus, sanguineus, Africans, Mexicans were identified based on eco-geographical grouping $[12,10,15]$. However, there is no difference in the chromosome number $(2 n=20)$ among the sub-species and they all can cross easily with each other $[12,16]$.

According [17] and [18], the castor can be classified as:

- Superdivision: Spermatophyta - Seed plants

- Division: Magnoliophyta - Flowering plants

- Class: Magnoliopsida - Dicotyledons

- Subclass: Rosidae

- Order: Euphorbiales

- Family: Euphorbiaceae - Spurge family

- Genus: Ricinus L. - Ricinus

- Species: Ricinus communis L. - Castor

According [19], castor must be classified as Angiospermae, Eudicotyledone, Rosanae and Malpighiales.

Although generally known as "castor bean", this plant is not a legume, and the term "bean" should be discontinued in favor of castor plant and castor seed [15] 2000). Avoiding to use the term bean is really important because these seed and the whole plant are very poisonous and should not be eaten.

A great variation in phenotypic expression is observed due to its cross-pollinated nature. Example of high variability in morphological characters are stem color, epicuticular wax

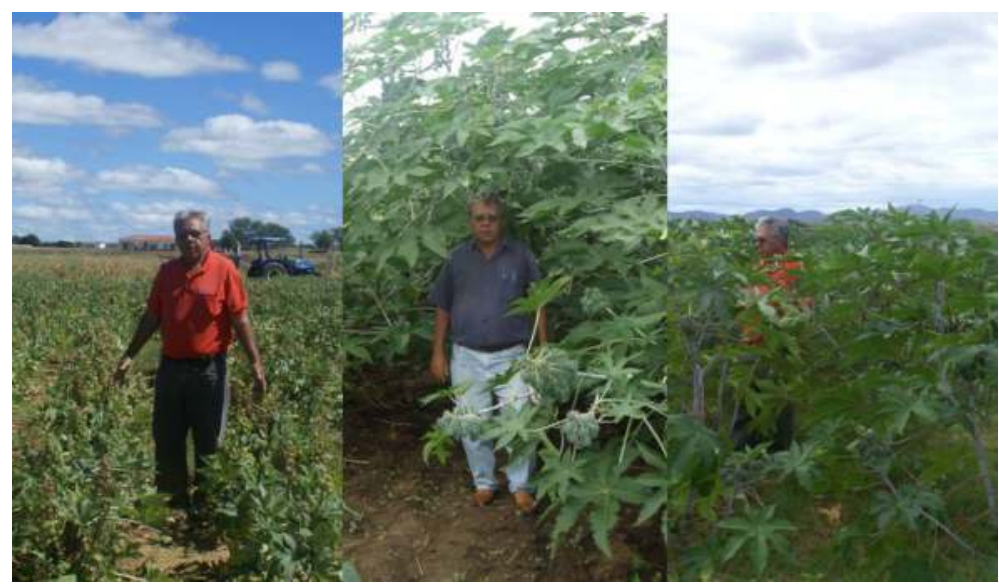

Figure 2. Examples of castor bean plants with different height. Photos: Máira Milani, Embrapa Cotton. 
(bloom wax), plant height (Figure 2), presence of spines on capsules (Figure 3), branching pattern, leaf shape, sex expression (Figure 4), seed color, and response to environmental conditions. Wide variation was observed in several morphological traits in the germplasm collections in India, USSR and elsewhere [14, 20, 15]. Also for quantitative traits its genetic polymorphism is exploitable in breeding programs [21, 22, 23, 24].

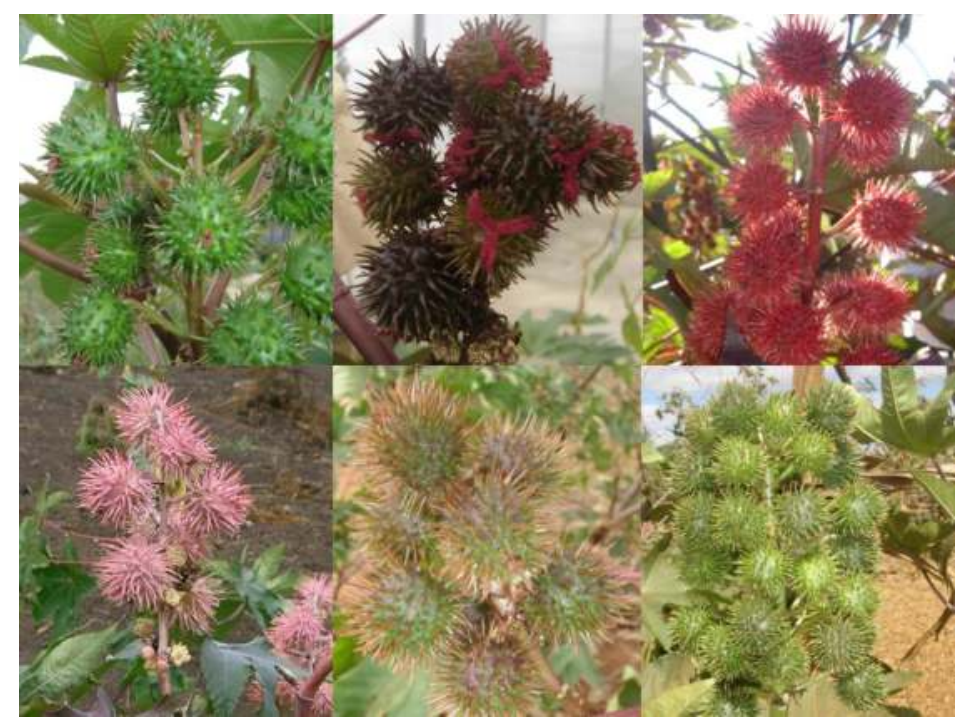

Figure 3. Examples of different colors in the fruits of castor bean. Photos: Máira Milani, Embrapa Cotton.

Germplasm banks are the basic providers of useful genes and genotypes needed to achieve the desirable genetic improvement in breeding programs; however, the resources available in castor germplasm worldwide have been barely tapped for castor genetic improvement and the majority of them have been poorly characterized [25]. The use of genetic resources by the global castor community could be increased if there were characterization of accessions, consolidated reports on available resources, free accession to information on banks, and uniform data collection standards among repositories [25].

These enhancements would allow an estimate of the genetic variability with single collections without the flux of accessions between countries. Germplasm characterization would also be easier if fast, non-destructive, and reliable screening methods were developed. An example is the quick and non-destructive method for estimating ricinoleic fatty acid content by Nuclear Magnetic Resonance in seeds [26].

Normally, castor is monoecious, with pistillate flowers on the upper part of raceme and staminate flowers on the lower part (Fig. 4a). This type is referred to as normal monoecious. Another type, referred as interspersed monoecious, has pistillate and staminate flowers interspersed along the entire raceme axis. The proportion of pistillate and staminate flowers 

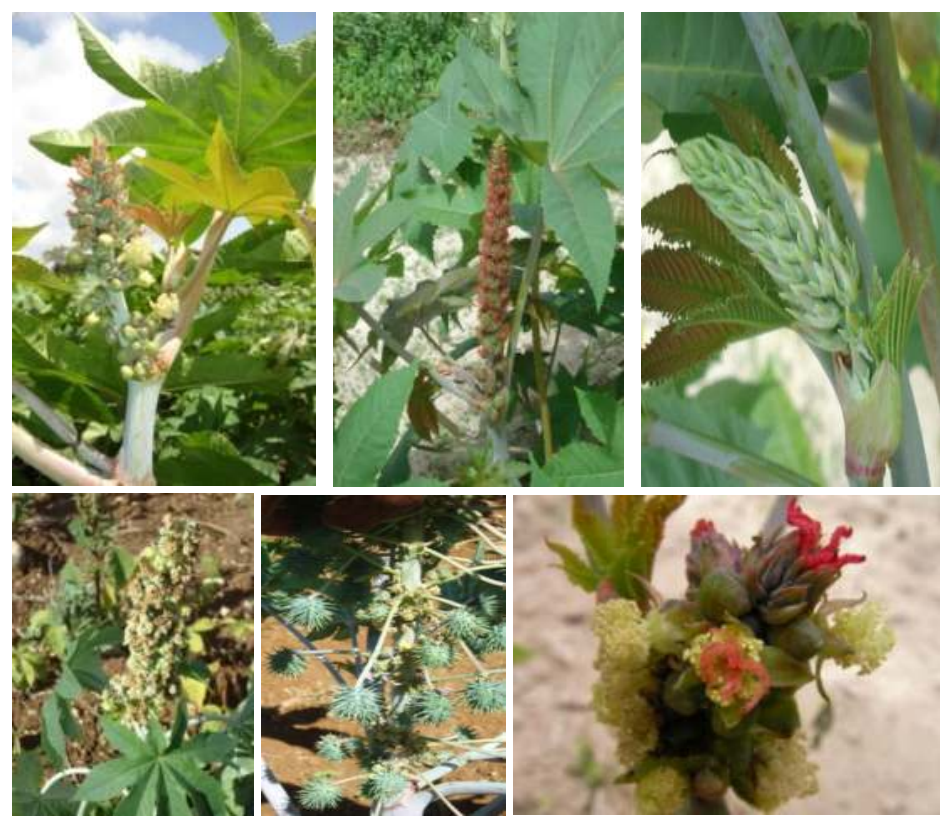

Figure 4. Arrangement of male and female flowers in racemes of castor: a)monoic normal; b and c) gynodioc; d) androdioic; e)interspersed; f) monoic bearing some perfect flowers.

among racemes can vary widely both within and among genotypes. It can also be influenced considerably by environment [27]

In normal monoecious varieties, the percentage of pistillate flowers along the raceme axis is usually the highest on the first raceme, with a decreasing percentage on subsequently developed racemes. With the decrease in pistillate flowers, there is a proportional increase in the number of staminate flowers [27]. This within plant variation is generally associated with the seasons. Female tendency is highest in spring and early summer; male tendency is highest in mid and late summer. Temperature is probably the main environmental component affecting sex. Moderate temperatures promote female flowers while high temperature promote male flowers. However, age of plant and nutrition can also influence sex expression. Femaleness is strongest in young plants with a high level of nutrition. Maleness is strongest in old plants with a low level of nutrition [28].

In addition to monoecism, a subtype of dioecism occurs in plants with only pistillate flowers along the entire raceme axis of all racemes [27]. The counterpart, plants with only staminate flowers, can occur in extreme climatic conditions, with high temperature or water deficit (Fig. 4d).

There are three types of pistillate lines (employed for hybrid production): N, S, and NES. In the $\mathrm{N}$ type, the femaleness is controlled by a recessive gene (ff). In the $\mathrm{S}$ type, femaleness is 
controlled by a polygenic complex with dominant and epistatic effects in which the plant starts as female, but a reversion can occur at any time. In the NES type, the plant has the recessive gene (ff) that allows it to start as female, but the presence of environmentally sensitive genes triggers a sexual reversion when temperature is higher than $31{ }^{\circ} \mathrm{C}[29,30,31]$.

The development of pistillate lines has allowed breeders to successfully utilize heterosis (hybrid vigor) in castor. Prior to the development of pistillate lines, inbred lines having many female flowers were used as female lines. Commercial exploitation of heterosis in India was instantly adopted after the development of VP-1, a S type stable pistillate line derived from TSP 10 R (Texas Stable Pistillate 10R) introduced from the USA [31]. Several pistillate lines were developed using VP-1 source of pistillate expression [32,33,34]. Other pistillate lines were developed using NES type of sexual expression but GCH-6 is the only commercial hybrid based on that system. Several other sources of pistillate lines were identified by screening 1 250 accessions from the germplasm bank at DOR, India [25, 34].

The adoption of male-sterile lines could be an alternative to pistillate lines for the production of hybrid seeds. Some studies were performed looking for genotypes with male sterility or inducing it through mutation [35], but we did not find any reference to a genotype expressing male-sterility for adoption into hybrid development programs.

A male flower, after opening, releases viable pollen grains for 1 to 2 days. The best environmental conditions for pollen dispersal are at a temperature between $26^{\circ} \mathrm{C}$ to $29^{\circ} \mathrm{C}$ and relative humidity of $60 \%$, which may vary according to the cultivar. The pollen contain allergenic substances similar to those found in the seeds, which are of protein nature, such as ricin, robina, crotin, and circina Arbina [15] 2000). High temperatures, plant age, and short day length favor the appearence of male flowers.

Regarding the female flowers, the literature shows that stigmas become receptive before the anthesis of male flowers. However the existence of this short protogynous phase [36] is not accepted by most researchers [37] who claim the male flowers reach maturity first and anthesis usually occurs in a short period of time before the opening of the female flowers [1]. In this way, there is a large source of pollen for the first pistillate flowers that open and become receptive. The stigma is fully receptive a few hours after the flower opens, but it is difficult for pollination to occur shortly after the opening of the flower. The stigma remains receptive after anthesis, , for a period of 5 to 10 days depending on environmental conditions [38].

Castor has a mixed mating system generating both selfed and cross fertilized offspring. Under natural conditions, cross pollination in castor can exceed $80 \%$ [11], but the actual level of cross pollination is dependent on both genotype and environmental conditions. Since pollination occurs mostly by wind, genetic purity of individual accessions can be maintained by planting in isolation by time or space (usually 1,000 $\mathrm{m}$ from other accessions) or covering the inflorescence with a paper bag [39]. This later option is labor intensive and expensive, but usually more practical if breeders need just a few seeds. Storing pollen is another option for germplasm conservation. [40] observed that castor pollen grains were viable after being stored at temperatures of $-196^{\circ} \mathrm{C},-80^{\circ} \mathrm{C}$, and $-18^{\circ} \mathrm{C}$ for up 30 days and there is evidence that pollen viability would be retained for long periods with cryopreservation at $-80^{\circ} \mathrm{C}$. 


\section{Goals of castor bean breeding}

Presently the main objectives of the breeding programs around the world are: earliness of seed maturation, plants architecture for mechanized harvest and disease resistance (root not and gray mold). These should be combined with superior productivity of cultivars and at least of $48 \%$ oil content of seed. Most breeding programs have searched genotypes with short height (less than $1.5 \mathrm{~m}$ ), height of primary raceme between 20 and $40 \mathrm{~cm}$, less than 150 days for harvesting, erect plant and non-shattering fruits.

In some regions, castor has have been selected for increased tolerance to abiotic stresses such as drought, high temperature, salinity, and exchangeable aluminium. Considering that the castor is not a food crop, it is often considered to be cultivated in marginal areas.

The reduction of the toxicity of castor seeds has also been the target of improvement programs. Ricin is a protein toxin found in the endosperm of castor seed capable of inhibiting protein synthesis by enzymatically blocking the ribosomes of eukaryotes [41]. Castor oil does not contain ricin because this protein is insoluble in oil, and any residual ricin is eliminated in the refining process. Ricin content varies among genotypes. The ricin content varied from 1.9 a 16 $\mathrm{g} / \mathrm{kg}$ among 263 accessions from the USDA Germplasm Bank [42] and from 3.5 to 32.2 in varieties and accessions from the Embrapa Germplasm Bank [43].

The development of new cultivars with traits of interest and adapted to specific microclimates is only possible when there is available knowledge about the extent of genetic diversity of the species [44]. Despite the recent publication of the castor bean genome [45], little is known about the actual genetic diversity of this species. Genetic diversity analyses of castor bean germplasm collections worldwide have showed low levels of variability and lack of geographically structured genetic populations, regardless of marker system used (e.g. [4, 46, 47]). Thus, the remarkable phenotypic variation observed in castor does not seem to reflect a high genetic diversity, similar to the one reported for physic nut, in which variations in epigenetic mechanisms may have a more important role in the diversity of the species than genetic variability per se [48]. Castor diversity is still poorly characterized by means of molecular marker systems $[49,50,51,52,53]$. In fact, the species has been overlooked until the late 2000s, when analyses regarding genetic diversity of germplasm collections were first published [46]. Thus, obtaining the desired genotypes implies the characterization of the germplasm banks and the proper publication of these results.

\section{Breeding methods}

In early phases of breeding programs, more attention is given to qualitative characters, but in later stages of improvement greater emphasis is shifted to quantitative traits such as yield, plant height, days to flowering, and traits associated with agronomic and economic factors.

Because castor has both self and crossed pollination and most of pollination is made by wind, contamination of varieties during seed production is a constant risk. To prevent contamination, 
it is necessary to isolate the area, physically (1000 meters) or temporally, or the use of selffertilization using paper bags (Fig. 4). Both strategies are expansive. The self-fertilization is a hand labor and normally demands many people and time. is practically impossible to keep the distance recommended in areas multiplication of lines, where they are multiplied dozens of strains simultaneously because it would require a large extension of the area.
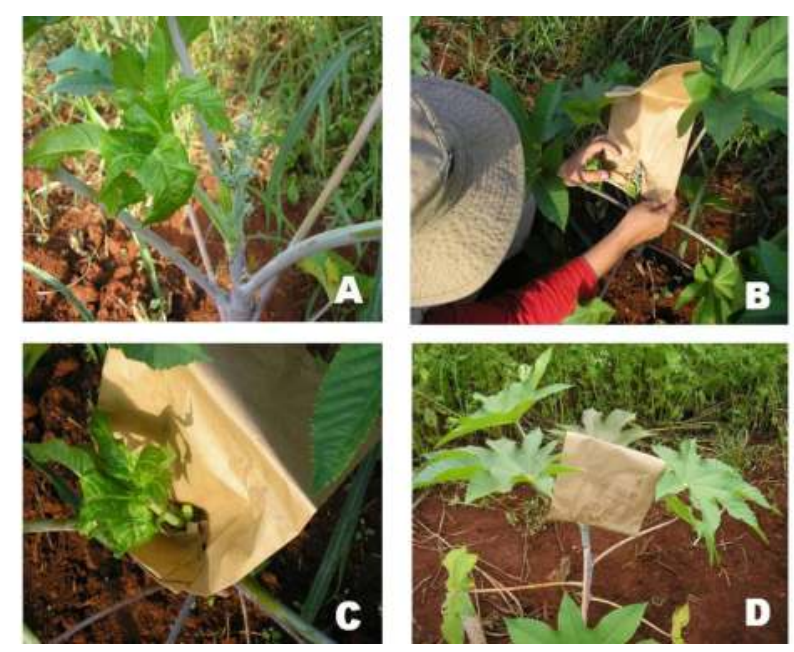

Figure 5. Self fertilization in castor. A) raceme with growing flowers; B) paper bag being placed over the raceme; C) Fixing paper bag; D) Identification. Photos of Marcia B. M. Nobrega, Embrapa Cotton.

Heterosis is a option for the development of hybrid cultivars of castor oil, representing an effective way to increase yield. In castor, this technique is possible due to the occurrence of gynodioecious plants whose genetic control is assigned to a recessive allele. However, the maintenance of female lines in castor increases the costs of production of hybrids. Thus, it is believed that the maintenance and propagation of female lines by micro propagation could be performed in vitro and therefore the purity of the female lines could be easily ensured, and manufacturing costs would be lower. Embrapa Cotton has been testing methods of clonal propagation in vitro and ex vitro in the castor, in order to regenerate and increase germplasm bank accessions, including a few female lines.

The cultivar development is divided into two main phases: pre-breeding and breeding. Both are essential to reaching its ultimate goal,which is to release new productive cultivars with wide adaptation, stability and good acceptance among producers. The pre-breeding, by definition, is the "bridge" between genetic resources and improvement [54]. In addition to the activities of these two steps it is essential to support activities of processes such as evaluation of the rate of outcrossing, asexual multiplication (in vitro and ex vitro), seed multiplication, and others. Each process is very important for the outcome. On average, the development of cultivars takes 10 to 12 years from the selection of germplasm to the legal process of plant variety protection. 
Embrapa Cotton with partners developed four castor cultivars using methods applied for inbreed populations: BRS Nordestina, BRS Paraguaçu, BRS Energia e BRS Gabriela. These varieties are recommended for the states of North and Northeast of Brazil.

BRS Nordestina stands out from the average height of $1.90 \mathrm{~m}$, greenish stems with the presence of wax, conical racemes, semi-dehiscent fruits, and black seeds. The period between emergence and first flowering raceme is 50 days, on average, while the average weight of 100 seeds is 68 $\mathrm{g}$, and the oil seed content is $48 \%$. The average yield is $1,500 \mathrm{~kg} / \mathrm{ha}$ under conditions of normal rainfall in the Northeast semiarid region. The period between the emergencee until the last harvest is 250 days. The BRS Paraguaçu has an average height of $1.60 \mathrm{~m}$, purple wax stem, oval raceme, semi-dehiscent fruits and black seeds. The period from emergence to flowering is 54 days, while the average weight weight of 100 seeds is $71 \mathrm{~g}$, and the oil seed content is $47 \%$. The average productivity is $1,500 \mathrm{~kg} / \mathrm{ha}$ under rainfed conditions of the semiarid region of the Northeast. Earliness is a key feature of BRS Energia, whose average cycle is 120 days between emergence and maturation of the last racemes. The appearance of the first raceme occurs about 30 days after germination. The yield of this cultivar is $1.800 \mathrm{~kg} / \mathrm{ha}$ under the same climatic conditions of the others. The average plant height is $1.40 \mathrm{~m}, 100$ seed weight is around $40 \mathrm{~g}$

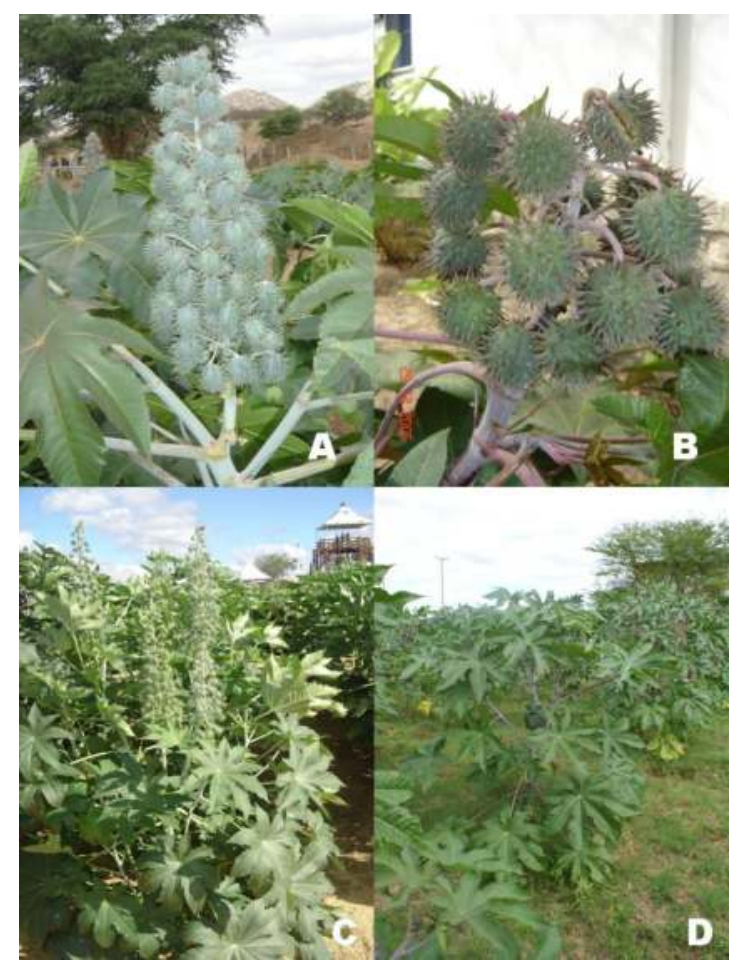

Figure 6. Embrapa's castor cultivars: (A) BRS Nordestina, (B) BRS Paraguaçu, (C) BRS Energia, and (D) BRS Gabriela. Photos of Máira Milani, Embrapa Algodão. 
and the seed oil content is $48 \%$. The BRS Gabriela has the highest seed oil content, $50 \%$ on average. It has a mean cycle of 150 days, productivity of $1900 \mathrm{~kg} / \mathrm{ha}$. The racemes have a round shape, immature green fruit with wax, an average density of spines, average density of fruit and green pink spines. Under extremes of precipitation (high or low), the density of fruits in racemes can be sparse. The fruits are indehiscent.

\subsection{Mass selection}

Mass selection consists in the selection of superior types and the discharge of undesirable types within a plant population. It is used for imprioved cultivars or established local types to improve, or standardize traits of economic importance.

Mass selection is the most effective method for characteristics with high heritability in populations with high levels of natural genetic variability. Two procedures are useful in increasing the efficiency of the mass selection in populations of castor: the self-fertilization of the selected plants to prevent cross pollination, and the use of controlled selection techniques to reduce environmental variation [55]. Mass selection was used to develop IAC-38, an important dwarf castor cultivar in Brazil [11]

\subsection{Individual plant selection with progeny tests}

This method consists in selecting individual plants and the subsequent study of their offspring in progeny trials. It is based on the principle that the breeding value of a plant may be measured by the performance of its progeny. It is a straightforward procedure to achieve greater uniformity and increased production in castor. The method of progeny test is highly effective for the improvement of populations of castor with high levels of natural genetic variability. This method was successfully used in the development of the high yielding cultivar 'Guarany' [56]

\subsection{Methods involving sexual hybridization}

When populations of castor with sufficient natural genetic variation for agronomic characteristics are not available, it is necessary to generate variability by producing hybrids between different lines or cultivars [55]. The choice of the parents of these populations must be based on their agronomic performance within the targeted production region, and diallel cross can be used if there are several promising parents or cultivars [55].

The pedigree method is adequate for simultaneous selection of several traits. This methods has been used to develop the cultivar IAC-2028, a dwarf and not-shattering genotype in Brazil [57].

The bulk method is the most effective option when the main objective is to improve the adaptation of castor to stress conditions such as drought, acid soils, high levels of salt and resistance to diseases [55]. The backcross method of selection is the most effective when there is a need to improve some simply inherited, qualitative characteristic in a commercial cultivar or promising elite line. The non-recurrent parent must have the characteristic absent from the 
recurrent parent. The method of backcrossing is especially effective in castor for the improvement of characteristics such as seed shattering, flower height, and disease resistance [55].

Recurrent selection is defined as successive cycles of selection and recombination of selected lines or individual plants [55]. It is not often used for castor selection, but it has been successful on the reduction of height of the cultivar Guarani $[58,59]$. In each of five cycles of selection, plant height was reduced by $28 \mathrm{~cm}, 13 \mathrm{~cm}, 19.9 \mathrm{~cm}, 11.7 \mathrm{~cm}$ and $3.4 \mathrm{~cm} \mathrm{[59].}$

In the last three decades, India has made significant progress in the development of hybrids [60]. The availability of pistilate lines, like the VP-1, was the base for launching hybrids such as GAUCH-1, GCH-2, and GCH-4 during 1990s and ten more high yielding hybrids later on [60].

The first commercial castor hybrid, 'GCH 3', was developed in India and had high seed yield potential ( $88 \%$ superior to the most planted cultivars at that time), drought tolerance, medium maturity time (140-210 days) and high oil content (46\%). Since then, a total of 15 hybrids were released in India, some of them with resistance to fusarium wilt and high seed yield potential [34]. The advantages of hybrids over cultivars resulted in a predominance of hybrids (50 to $60 \%$ ) in the castor production in India. In the State of Gujarat, the use of hybrid seed is up to $95 \%$ of the cultivated area. In Gujarat, where castor is cultivated mostly under irrigated conditions, the adoption of hybrid seed has caused an increase in seed yield from 350 to 1970 $\mathrm{kg} / \mathrm{ha}$ within a few years [34].

The intensity of heterosis on castor seed yield depends on both the genetic diversity and individual combining ability of the parents [61, 62, 63, 64, 32, 33, 34]. More studies on genetic diversity and combining ability are necessary for supporting the development of hybrids.

An alternative method for selecting castor hybrids was successfully evaluated by Toppa [65]. The method of cryptic hybrids was proposed by Lonqquist [66] for maize, consisting of simultaneous self-pollination and crossing in the same plant, allowing the selection of the best progeny at each cycle. Because castor has a low endogamic depression and produces more than one raceme per plant, the method can be employed. After four cycles of selection, the 12 cryptic hybrids had higher seed yield $(1,675 \mathrm{~kg} / \mathrm{ha})$ than the 12 conventional hybrids $(1,550 \mathrm{~kg} /$ ha) evaluated over two years in two locations [65].

\section{Challenges}

The scarcity of labor that has been observed in rural areas over the past decade, has raised the costs of operation management and cultivation. A research group in Brazil has been focusing on the research for indehiscent cultivars with shorter plants to facilitate mechanical harvesting operations. Also earlier genotypes have been obtained to reduce the residence time of the crop in the field.

In a review of the challenges to reach greater productivity with the castor [67], the authors mention that the main challenge in developing cultivars is the castor plant adaptation to 
Combine harvesting. Both cultivars as machines, require further adjusted in order to obtain more efficiency in the process of Combine harvesting.

Nowadays, breeders look for plants that could be adapted for a variety environmental conditions including the increased ambient temperature caused by Global Climate Change.

\section{Author details}

Máira Milani and Márcia Barreto de Medeiros Nóbrega

Embrapa Cotton, Campina Grande, Paraíba, Brazil

\section{References}

[1] Brigham RD. Castor: Return of an old crop. In Janick J; Simon JE (ed.) Progress in New Crops. New York: Wiley, 1993. 380-383.

[2] Chierice GO; Claro Neto S. Aplicação industrial do óleo. In: Azevedo DMP; Beltrão NEM (Ed.). O Agronegócio da mamona no Brasil. Brasília, DF:Embrapa Informação Tecnológica, Campina Grande: Embrapa Algodão, 2007, 417-447.

[3] CASTOROIL.IN Comprehensive Castor Oil Report: A report on castor oil \& castor oil derivatives, in: http://www.castoroil.in/reference/report/report.html. (Accessed 31 january 2013)

[4] Foster JT, Allan GJ, Chan AP, Rabinowicz PD, Ravel J, Jackson PL. Single nucleotide polymorphisms forasses sing genetic diversity in castor bean (Ricinus communis). BMC Plant Biol. , 201010:13-23. doi:10.1186/1471-2229-10-13

[5] FAOSTAT http://faostatfao.org/site/567/DesktopDefault.aspx?PageID=567\#ancor 2012 (accessed 12 november 2012)

[6] Carvalho BCL. Manual do cultivo da mamona. Salvador: EBDA. 2005

[7] CONAB. Série histórica: mamona. Brasília, DF: Central de Informações Agropecuárias. http://www.conab.gov.br/conteudos.php?a=1382\&t=2. (Accessed 31jan2013)

[8] Savy Filho A. Mamona: tecnologia agrícola. Campinas: Emopi, 2005

[9] Freire EC; Lima EF; Andrade FP; Milani M; Nóbrega MBM. Melhoramento genético. In: Azevedo DMP; Beltrão NEM (Ed.). O Agronegócio da mamona no Brasil. Brasília, DF:mbrapa Informação Tecnológica, Campina Grande: Embrapa Algodão, 2007. 169-194

[10] Moshkin VA. Castor. New Delhi: Amerind; 1986 
[11] Savy Filho A. Castor bean breeding. In: Borém A (Ed.) Improvement of Cultivated Species. Viçosa: Federal University of Viçosa, 2005

[12] Kulkarni LG, Ramanamurthy GV. Castor. New Delhi: Indian Council of Agric Res., 1977

[13] DOR. Castor in India. Hyderabad: Directorate of Oilseeds Research. 2003

[14] Anjani K. Extra-early maturing germplasm for utilization in castor improvement. Ind. Crops Products 2010, 31, 139-144

[15] Weiss EA. Oilseed crops. 2nd ed. Oxford: Blackwell Science, 2000

[16] Atsmon D. Castor. In: Röbbelen G, Downey RK, Ashri A (Eds.) Oil Crops of the World. New York: McGraw Hill, 1989; p 348-447,

[17] Vidal WN, Vidal MRR. Fitossistemática: famílias de angiospermas.Viçosa: UFV, 1980. 59.

[18] Popova GM, Moshkin VA. Botanical classification. In: Moshkin VA (Ed.). Castor. New Delhi: Amerind, 1986

[19] Angiosperm Phylogeny Group III. An update of the Angiosperm Phylogeny Group classification for the orders and families of flowering plants: APG III. Botanical Journal of the Linnean Society, London, 2009, 161: 105 - 121

[20] Moshkin VA, Dvoryadkina AG. Cytology and genetics of qualitative characters. In: Moshkin VA Castor. New Delhi: Amerind, 1986. 93-102

[21] Uguru MI, Abuka IN. Hybrid vigour and genetic actions for two qualitative traits in castor plant (Ricinus communis L.). Ghana Journal. Agric. Sci. 1998; 31: 81 - 82

[22] Bahia HF, Silva SA, Fernandez LG, Ledo CAS, Moreira RFC. Divergência genética entre cinco cultivares de mamoneira. Pesquisa Agropecuária Brasileira, 2008. 43, 357-362.

[23] Bezerra Neto FV, Leal NR, Gonçalves LSA, Rêgo Filho LM, Amaral Júnior AT. Descritores quantitativos na estimativa da divergência genética entre genótipos de mamoneira utilizando análises multivariadas Rev. Ciênc. Agron., 2010, 41, 294-299

[24] Nóbrega MBM, Geraldi IO, Carvalho ADF. Avaliação de cultivares de mamona em cruzamentos dialélicos parciais. Bragantia 2010. 69. 281-288

[25] Anjani K. Castor genetic resources: a primary gene pool for exploitation. Ind. Crops. Products 2012.35:1-14 doi: 10.1016/jindcrop.2011.06.011.

[26] Berman P, Nizri S, Parmet Y, Wiesman Z. Large scale-scale screening of intact castor seeds by viscosity using time domain NMR and chemometrics. J. Am. Oil Chem. Soc. 2010. 87:1247-1254.doi:10.1007/s11746-010-1612-z. 
[27] Zimmerman LH, Smith JD. Production of F1 seed in castorbean by use of sex genes sensitive to environment. Crop Science, 1966, 6: 406-409

[28] Shifriss O. Sex Instability in Ricinus. Genetics, 1956, 41: 265-280.

[29] Zimmerman, L. H. Castorbeans: a new crop for mechanized production. Adv. Agron. (1958). X:, 257-288.

[30] Shifriss, O. Conventional and unconventional systems controlling sex variations in Ricinus. J. Genet. (1960).

[31] Ankineedu G, Rao GP. Development of pistillate castor. Indian J. Genet. Plant Breeding 1973, 33:416-422

[32] Lavanya C, Ramanarao PV, Gopinath VV. Studies on combining ability and heterosis in castor hybrids. Journal of Oilseeds Research 2006, 23:174-177.

[33] Pathak HC. Crop Improvement in Castor. In D.M. Hegde (ed.) Vegetable Oils Scenario: Approaches to Meet the Growing Demands. Hyderabad: Indian Society of Oilseeds Research, 2009. 82-94

[34] Lavanya C, Solanki SS. Crop improvement of castor. The challenges ahead. In Hegde DM (ed.). Research and Development in Castor. Present status and future strategies. Hyderabad: Indian Society of Oilseeds Research, 2010, p 36-55

[35] Chauhan SVS, Singh KP, Kinoshit T. Gamma-ray induced pollen sterility in castor. J. Fac. Agric. Hokkaido Univ. 1990.64, 229-234

[36] Gurgel JT. Estudos sobre a mamoneira (Ricinus communis L.). Thesis for teaching profession. ESALQ/USP; 1945

[37] Tavora FJAF. A cultura da mamona. Fortaleza: Epace, 1982

[38] Moreira JAN, Lima EF, Farias FJC, Azevedo, DMP. Melhoramento da mamoneira (Ricinus communis L.). Campina Grande. Embrapa/CNPA, 1996

[39] Rizzardo RAG. O papel de Apis mellifera L. como polinizador da mamoneira (Ricinus communis L.):avaliação da eficiência de polinização das abelhas e incremento de produtividade da cultura, MS thesis.Universidade Federal do Ceará; 2007

[40] Vargas DP, Souza SAM, Silva SDA, Bobrowski VL. Pollen grain analysis of some cultivars of castor-oil plant (Ricinus communis L., Euphorbiaceae): conservation and viability. Arquivos do Instituto Biologico 2009. 76, 115-120

[41] Khvostova IV. Ricin: the toxic protein of seed. In: Moshkin VA (Ed.) Castor. New Delhi: Amerind Publ., 1986. p 85-92

[42] Pinkerton SD, Rolfe RD, Auld DL, Ghetie V, Lauterbach BF. Selection of castor with divergent concentrations of ricin and Ricinus communis agglutinin. Crop Sci. 1999; 39:353-357 
[43] Baldoni AB, Carvalho MH, Sousa NL, Nobrega MBM, Milani M, Aragão FJL. Variability of ricin content in mature seeds of castor bean. Pesquisa Agropecuária Brasileira, 46, , 2011. 776-779

[44] Gepts, P. Crop domestication as a long-term selection experiment. In: Janick J. (Ed.) Plant Breeding Reviews, Habaken: John Wiley \& Sons, Inc., (2004). , 24, 1-44.

[45] Chan AP, Crabtree J, Zhao Q, Lorenzi H, Orvis J, Puiu D, Melake-Berhan A, Jones KM, Redman J, Chen G, Cahoon EB, Gedil M, Stanke M, Haas BJ, Wortman JR, Fraser-Liggett CM, Ravel J, Rabinowicz PD. Draft genome sequence of the oilseed species Ricinus communis. Nat. Biotechnol. 2010; 28:951-956. doi:10.1038/nbt.1674.

[46] Allan G, Williams A, Rabinowicz PD, Chan AP, Ravel J, Keim P. Worldwide genotyping of castor bean germplasm (Ricinus communis L.) using AFLPs and SSRs. Genet. Resour. Crop Evol. 2008; 55:365-378.doi:10.1007/s10722-007-9244-3

[47] Qiu LJ, Yang C, Tian B, Yang JB, Liu AZ. Exploiting EST databases for the development and characterization of EST-SSR markers in castor bean (Ricinus communis L.). BMC Plant Biol. 2010; 10:278-287. doi:10.1186/1471-2229-10-278

[48] Yi C, Zhang S, Liu X, Bui H, Hong Y. Does epigenetic polymorphism contribute to phenotypic variances in Jatropha curcas L.? BMC Plant Biology 2010; 10: 1-9

[49] Billotte N, Jourjon M, Marseillac N, Berger A, Flori A, Asmady H, Adon B, Singh R, Nouy B, Potier F, Cheah S, Rohde W, Ritter E, Courtois B, Charrier A, Mangin B. QTL detection by multi-parent linkage mapping in oil palm (Elaeis guineensis Jacq.). Theoretical and Applied Genetics, 2010; 120, 1673-1687

[50] Feng S, Li W, Huang H, Wang J, Wu Y. Development, characterization and cross-species/genera transferability of EST-SSR markers for rubber tree (Hevea brasiliensis). Molecular Breeding, 2009; 23: 85-97

[51] Sayama T, Hwang TY, Komatsu K, Takada Y, Takahashi M, Kato S, Sasama H, Higashi A, Nakamoto Y, Funatsuki H, Ishimoto M. Development and application of a whole-genome simple sequence repeat panel for high-throughput genotyping in soybean. DNA Research, 2011; 18:107-115

[52] Sraphet S, Boonchanawiwat A, Thanyasiriwat T, Boonseng O, Tabata S, Sasamoto S, Shirasawa K, Isobe S, Lightfoot DA, Tangphatsornruang S, Triwitayakorn K. SSR and EST-SSR-based genetic linkage map of cassava (Manihot esculenta Crantz). Theoretical and Applied Genetics, 2011; 122: 1161-1170

[53] Talia P, Nishinakamasu V, Hopp HE, Heinz RA, Paniego N. Genetic mapping of EST-SSRs, SSR and In Dels to improve saturation of genomic regions in a previously developed sunflower map. Electronic Journal of Biotechnology, 2010; 13: 6

[54] Nass LL. Utilização de recursos genéticos no melhoramento. In: Nass LL, Valois ACC, Melo IS, Valadares-Inglis MC. Recursos genéticos e melhoramento de plantas. Rondonópolis: Fundação MT, 2001; 29-56 
[55] Auld DL, Zanotto MD, Mckeon T, Morris JB. Castor. In: Vollmann J, Rajcan I. (ed.) Oil Crops - Handbook of Plant Breeding. New York: Springer, 2009, 316-332

[56] Amaral JGC Genetic variability for agronomic characteristics between self pollinated lines of castor (Ricinus communis Lcv. AL Guarany. Ph. Dissertation, College of Agronomic Sciences, São Paulo State University; (2003).

[57] Savy Filho A, Amorim EP, Ramos NP, Martins ALM, Cavichioli JC. IAC 2028: nova cultivar de mamona. Pesq. agropec. bras., 2007, 42:449-452

[58] Zanotto MD, Amaral JGC, Poletine JP. Recurrent selection with use of self pollinated lines for reduction of the height of plants of castor (Ricinus communis L.) in a common Guarani population. Proc. Congresso Brasileiro de Mamona, 1st, 2004, 1:1-5. Campina Grande. Embrapa Algodão, Campina Grande, 2004

[59] Oliveira IJ, Zanotto MD. Efficiency of recurrent selection for reduction of the stature of plants in castor (Ricinus communis L.). Cienc. Agrotecnol. 2008, 32:1107-1112. doi: 10.1590/S1413-70542008000400011.

[60] Sujatha M, Reddy TP, Mahasi MJ. Role of biotechnological interventions in the improvement of castor (Ricinus communis L.) and Jatropha curcas L. Biotechnol. Adv. 2008; 26:424-435. doi:10.1016/j.biotechadv.2008.05.004

[61] Costa MN, Pereira WE, Bruno RLA, Freire EC, Nóbrega MBM, Milani M, Oliveira AP. Genetic divergence on castor bean accesses and cultivars through multivariate analysis. Pesquisa Agropecuária Brasileira, 2006; 41:1617-1622. doi: 10.1590/ S0100-204X2006001100007

[62] Golakia PR, Madaria RB, Kavani RH, Mehta DR. Gene effects, heterosis and inbreeding depression in castor, Ricinus communis L. Journal of Oilseeds Research, 2004; 21:270-273

[63] Lavanya C, Chandramohan Y. Combining ability and heterosis for seed yield and yield components in castor. Journal of Oilseeds Research, 2003;20:220-224

[64] Ramana PV, Lavanya C, Ratnasree P. Combining ability and heterosis studies under rainfed conditions in castor (Ricinus communis L.,). Indian Journal of Genetics and Plant Breeding, 2005, 65:325-326

[65] Toppa EVB. Análise comparativa da produtividade de híbridos de mamoneira (Ricinus communis L.) obtidos por meio da hibridação convencional e do método dos híbridos crípticos. Ph dissertation, FCA/Unesp. 2011

[66] Lonnquist JH, Williams NE. Development of maize hybrids through among full-sib families. Crop Sci. 1967; 7:369-370

[67] Severino LS, Auld DL, Baldanzi M, Cândido MJD, Chen G, Crosby W, Tan D, et al. A Review on the Challenges for Increased Production of Castor. Agronomy Journal, 2012; 104(4):853-879. doi:10.2134/agronj2011.0210 